\title{
エサルハドンの王碑文における反乱の記述とその役割
}

\section{Accounts of Rebellion and Their Role in the Royal Inscriptions of Esarhaddon}

青 島 忠一朗

AOSHIMA Chuichiro

\begin{abstract}
This paper discusses how rebellions were described in the Assyrian royal inscriptions and the role of such descriptions, taking the inscriptions of Esarhaddon as an example.

The inscription written in 676 BC (RINAP 4, No. 2) describes only the event concerning BìtDakkuri as a rebellion. In contrast to this inscription, a later inscription written in 673 BC (RINAP 4, No. 1) begins with an "apology" that details Esarhaddon's succession through suppressing the coup of his brothers, and then reports the rebellions in the "Sea land" and in Sidon, which are not described as rebellions in the earlier inscription.

The addition of the "apology" and the rewriting of the accounts are related to the political circumstances at the time of the composition of the inscription: the Assyrian defeat in Egypt and the appointment of Ashurbanipal as the crown prince. These events pressed Esarhaddon to legitimate his authority and to pay more attention to the risk of rebellion. The series of accounts of rebellions placed at the top of the inscription functioned to warn potential rebels against plotting a rebellion, by presenting typical rebellions by ruling elites and describing the fate that they met.

The ruler of Arzā, whose behavior is not described as rebellious in the earlier inscriptions, is first described as a rebel in the inscription written after the conquest of Egypt (RINAP 4, No. 30). Arzā had been topographically important as the boundary that was used to glorify royal deeds in Assyrian royal inscriptions. Therefore the campaign to Arzā had been described as military activity in a foreign land, but after the conquest of Egypt the city lost its significance as the boundary.
\end{abstract}

キーワード：アッシリア王碑文, 反乱, 王の描写, エサルハドン王位継承誓約, 弁明

\section{I. はじめに}

アッシリア王碑文は, 前 2 千年紀後半から前 1 千年紀前半にかけて, 王の建設事業や軍事遠征な どを記念し，王の治世中に幾度も編集された。王を称え，王の業績を神々と後世の支配者に伝え るために記されたアッシリア王碑文は, 事実の誇張や歪曲あるいは隠蔽などを通じて王の偉大さや 功績を際立たせた。王碑文のこうした叙述の傾向や情報操作はすでに研究の対象となってきたが

* 中央大学人文科学研究所客員研究員

Guest Fellow, The Institute of Cultural Science, Chuo University

（1）アッシリア王碑文の概要はGrayson 1980, 150-159. 本稿で使用する略号はM. T. Roth et al. (eds.), The Assyrian Dictionary of the Oriental Institute of the University of Chicago, vol. 20, $U$ and W, Chicago, IL, 2010, viixxixに準拠する。 
(Grayson 1965; Laato 1995; 山田 2003b), 外国遠征とともに遠征記事の大きな主題となる反乱とそ の鎮圧に関する記述については，これまで大きな関心が寄せられることはなかった。しかしながら， 反乱とは，たとえ鎮圧したとしても，王にとって必ずしも名誉となり得る出来事ではない。そのた め, 同じく敵対者に対する勝利ではあっても, 反乱の平定はアッシリアの外部に対する征服活動と は異なる基準や原則に則って記され，対外遠征よりも入念な情報操作が施されたと考えられる。事 実, 遠征記事のなかには, 鎮圧した反乱であっても, 反乱者に対する懲罰という遠征理由に言及し ないケースがあり, さらには同じ出来事を反乱として明記するか否かが碑文によって異なるケース も見られる。それゆえ, 反乱に関する叙述の傾向とその役割を明らかにすることは, 王碑文の叙述 の傾向と編集プロセスの更なる理解にとって欠かすことのできない作業である。

筆者はすでにこの点について指摘し，アッシュルナツィルパル 2 世（在位前 883-859年）の王碑文 における反乱の記述を取り上げて，とくに反乱として明記されなかった反乱の記述を中心に論じた （青島 2016）。しかしながら, 反乱として明記された事例および碑文によって反乱の明記・不明記が 変化する事例に関する考察は, 十分に行なえたとは言い難い。そこで本研究では, エサルハドン（在 位前 680-669年）の王碑文のうち 3 点を取り上げ，とくにこの 2 種類の反乱記述について考察する。

本研究でエサルハドンの王碑文を選んだ理由は, 次の 2 点である。エサルハドンの王碑文には, 個別の反乱が複数の碑文において記される際，3つのパターンが見られる。すなわち，1）反乱とし て明記された事例，2）反乱であるにもかかわらず，反乱として明記されない事例，3）同一の反乱 を扱っていても，碑文によって反乱の明記・不明記が変化する事例が見受けられる。さらに，この 王の時代に属する史料は王碑文以外にも王室書簡, 歴代誌, 占い文書, 誓約文書と数多く現存して おり, 治世中に起きた出来事の詳細な歴史的再構成も行われている。そのため, これらの史料と研 究を利用することで, 王碑文が伝える反乱とそれに関する記事の内容が変化した背景について, 明 瞭な推察が可能である。

以下, エサルハドンの王碑文に扔ける反乱記述を関連する王碑文外史料も用いながら考察し,アッ シリア王碑文における反乱に関する叙述の傾向とその背景の一端を明らかにしたい。

\section{II. 先 行 研 究}

エサルハドンの王碑文における反乱に関する叙述の傾向とその背景を含めた考察は, 一般に「弁 明」（apology）と呼ばれるエサルハドンの王位継承に関する騒乱を主題にした記事に集中してい る。古代オリエントにおいて, 王位篡奪を含め, 異例な形で王位についた王の碑文には, しばしば 即位の経緯を伝える「弁明」が記された。「弁明」は, 前王や他の候補者の振る舞いを非難し, 規 範から外れた即位の経緯を釈明的に語ることで, 現王の王位の正当性を強調する役目を果たした (Tadmor 1983, 36; Knapp 2015, 45-56)。

タドモール（Tadmor 1983，37-47）は，エサルハドンの「弁明」がこの王の治世後半（前 673年） に編集されたNo. 1 に初めて記された点に注目し ( , 「弁明」の記載を碑文編集時の政治状況から考察 
した。そして，No.1における「弁明」の記載と海の国の反乱に関する記事の書き換えは, No. 1が 編集された翌年（前672年）に行われたアッシュルバニパル（在位前 668-627年）の王位継承に関 する誓約式と関係し，エサルハドンの王位の正当性の強調とそれを通じたアッシュルバニパルの皇 太子指名を正当化するとともに，誓約を破ることの恐ろしさを喧伝する目的があったと論じた。

タドモールは示唆にとどめたが（Tadmor 1983, 41-42), No. 1における「弁明」の記載は, 前年 に起きたエジプト遠征の失敗（前 674年）とも関係していると考えられる。エフアル（Eph`al 2014， 58-60）によると, アッシリア軍の敗北によって, エサルハドンの権威が失墜し, 反乱勃発の危険 性が増大したことも, 王位の正当性を喧伝する「弁明」がNo. 1に記された理由であった。エサル ハドンの「弁明」を再検討したクナップ（Knapp 2016, 191）も，同様の観点を重視した見解を提出 している。

これらの研究は，エジプトでの敗北とアッシュルバニパルの王位継承に関する誓約式がNo. 1 の 叙述に影響したという点で基本的に一致し、「弁明」はエサルハドンの王位と彼によるアッシュル バニパルの皇太子指名の正当化を目的にしたとする。筆者もこの見解に異論はない。しかし, No. 1では「弁明」の追加, 海の国の記事の変化に加え, シドン遠征も反乱鎮圧を目的とした遠征とし

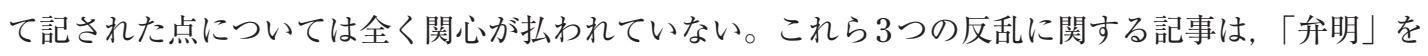
先頭にNo. 1の冒頭部に連続して配置される。そのため, この一連の記事は反乱を主題とする一つ のまとまりとして考察する必要があると考えられる。

さらに,「弁明」は上述のタドモールやエフアルなどの研究に加え, 記事で用いられた表現まで もが詳細に論じられたのに対し (Frahm 2009), 「弁明」以外の反乱に関する記述の多くは, 主に歴 史再構成のために用いられてきた。そのため, 反乱を扱う他の記事についても, 叙述の傾向や碑文 間での記述の変化とその背景などについて考察する必要がある。

\section{III. 史料}

本研究で史料として扱うのは，ニネヴェから出土した前 676年編集の碑文（RINAP 4, No. 2, 以 下No. 2)，主にニネヴェとアッシュルから発見された前 673 年に記された碑文（RINAP 4, No. 1, 以下No. 1), そして前 671年以降に編集されたと考えられるニネヴェ出土の碑文の断片（RINAP 4, No. 30, 以下No. 30) の3 点の王碑文である。

軍事遠征記事を含むアッシリア王碑文の叙述様式は, 大きく2つに分けられる（Grayson 1980, 150-155)。一つは遠征をリンム年や「治世年 (palu) 」あるいは「遠征 (girru)」で数え, 各遠征 を年代順に記し, 進軍や敵との戦闘の様子を詳細に描く年代記，もう一つは遠征を地域毎にまとめ, 戦果を簡潔に記す要約碑文である。

本研究で扱う 3 つ碑文のうち, No. 1 とNo. 2 の遠征記事は, 遠征をリンム年等で年代づける

（ 3 ） 例えばアラブの反乱についてはEph`al 1982, 128-129, 海の国とビート・ダックリの反乱についてはFrame 1992, 65-66, 79-81を参照。

（4）碑文の編集年代についてはRINAP 4, 19,27を参照。No. 30 は断片だが，ティルスの征服が記されているので, エサルハドンの第 2 回エジプト遠征（前671年）以降に記されたと考えられる。

（５）アッシリア王碑文の年代記様式と様式の発展については山田 2003a を参照。 
ことはなく，基本的に地域毎にまとめられているため，要約碑文に分類される（Eph`al 2014, 52）。 No. 1 の遠征記事の多くはNo. 2 と類似しており, 記事の配列も似ているため, No. 1 はNo. 2 をも にして編集されたと考えられる。No. 30 は碑文の断片であるために全容は不明だが, No. 1 が伝え るいくつかの遠征を簡潔に伝える。一部の記事はNo. 1と並びが異なるものの, この碑文の記事も 遠征を年代づけることはしないため, 要約碑文と考えられる。

\section{IV. アッシリア王碑文における反乱の記述}

アッシリアの支配領域は, アッシリア王が任命した知事によって直接統治された属州と属王とし て擁立した現地の支配者を通じて間接統治された属国からなる。アッシリアは, 理念的には一度アッ シリアの支配を受け入れた国や支配者を永続的に支配下にあるものとみなした。そして, 王の敷く 秩序に対するあらゆる反抗を反乱とみなし，制裁の対象とした。

王碑文はこうした秩序を乱す者に対する遠征に言及するが，反乱平定を目的とした遠征の記事は， 反乱を明記する記事と明記しない記事の 2 種類に分けられる。反乱として明記する記事をここでは 反乱記事と呼ぶことにする。反乱記事の特徴は, 記事冒頭で遠征理由となった反乱の内容を伝える 点である。しかし, これに続く部分は王の出陣, 戦闘描写, 敵に対する勝利, 戦後処理からなり, 記事の構成は外国征服を主題とする対外遠征記事とほとんど変わらない。

反乱として明記しない記事は, 遠征理由を挙げないまま, 属国や属州に対する軍事行動を伝えて いる。この場合, 記事の構成は対外遠征を主題とする記事と変わらないため, 両者の区別は困難で ある。

記事で主題となった遠征がアッシリアの外部に対する征服活動であるのか, それとも反乱平定を 目的とした軍事活動であるのかは, 遠征先となった国や支配者がアッシリアの支配下に入ったこと があるかどうかを基準として判断する。

\section{V.エサルハドンの王碑文における反乱の記述}

表1は，No. 1，2，30の3つの碑文を編集年代順に並べ，遠征記事の内容を記載順に一覧にした ものである。反乱を扱う記事は色づけし, 反乱描写の有無を付してある。碑文に登場する反乱した 国や地域については，図1を参照されたい。

\section{No. 2 における反乱の記述}

No. 2では, シドン，アルザー，ヒラック，マンナイ，海の国，そしてビート・ダックリに対す る遠征を記した記事が反乱を扱っている。しかし，ビート・ダックリを除き，いずれの出来事も反

（６）アアシリアの支配体制についてはYamada 2000, 300-308を参照。

（７）これは, アダド・ネラリ 2 世（在位前911-891年）が数百年前からの貢納の滞納を理由に懲罰遠征を行ったこ とにも明示される（RIMA 2, A.0.99.2, 85-86)。 

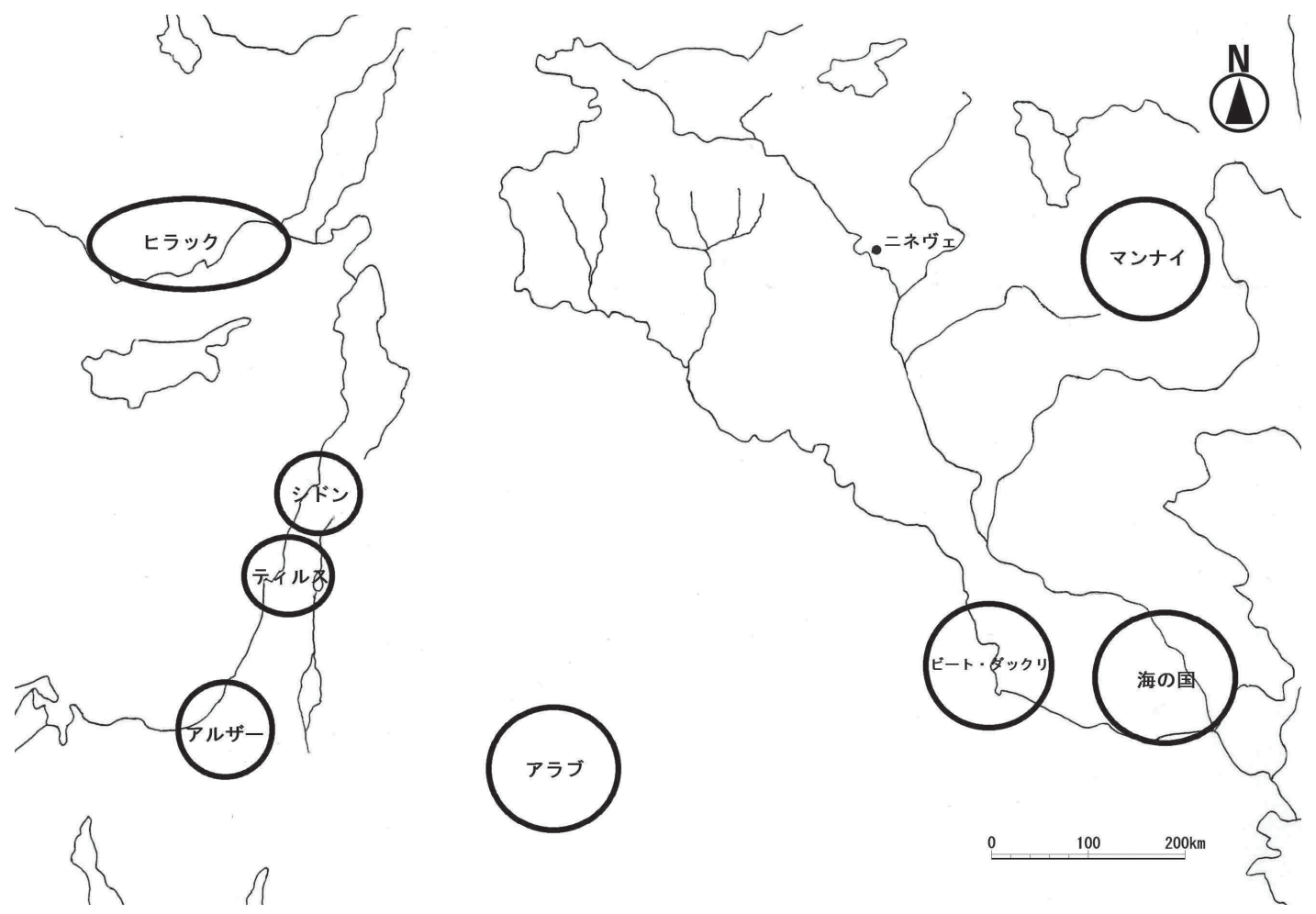

図1 エサルハドン治世中に反乱した諸国

表1 No. 1, No. 2, No. 30 における反乱を扱った記事

\begin{tabular}{|l|c|c|}
\hline \multicolumn{1}{|c|}{ No. 2 } & 遠征地 & $\begin{array}{l}\text { 反乱 } \\
\text { 描写 }\end{array}$ \\
\hline i 1-13 & 導入部 & \\
\hline i 14-37 & シドン & 無 \\
\hline i 38-56 & クンドゥ・シッス & \\
\hline i 57-63 & アルザー & 無 \\
\hline ii $1-4$ & キンメリア人 & \\
\hline ii 5-15 & ヒラック & 無 \\
\hline ii $16-19$ & バルナキ & \\
\hline ii 20-23 & マンナイ & 無 \\
\hline ii 24-33 & 海の国 & 無 \\
\hline ii 34-45 & ビート・ダックリ & 有 \\
\hline ii $46-$ iii 8 & アラブの貢納 & \\
\hline iii 9-36 & バーズ & \\
\hline iii 37-52 & ガンブルの貢納 & \\
\hline iii $53-$ iv 20 & メディア & \\
\hline
\end{tabular}

\begin{tabular}{|l|c|l|}
\hline \multicolumn{1}{|c|}{ No. 1 } & 遠征地 & $\begin{array}{l}\text { 反乱 } \\
\text { 描写 }\end{array}$ \\
\hline i 1-7 & 導入部 $(1)$ & \\
\hline i 8-ii 11 & 「弁明」 & 有 \\
\hline ii 12-39 & 導入部 (2) & \\
\hline ii 40-64 & 海の国 & 有 \\
\hline ii 65-iii 19 & シドン & 有 \\
\hline iii 20-38 & クンドゥ・シッス & \\
\hline iii 39-42 & アルザー & 無 \\
\hline iii 43-46 & キンメリア人 & \\
\hline iii 47-55 & ヒラック & 無 \\
\hline iii 56-58 & バルナキ & \\
\hline iii 59-61 & マンナイ & 無 \\
\hline iii 62-70 & ビート・ダックリ & 有 \\
\hline iii 71-83 & ガンブルの貢納 & \\
\hline iv 1-31 & アラブ & 有 \\
\hline iv 32-52 & メディア & \\
\hline iv 53-77 & バーズ & \\
\hline iv 78-v 25 & 要約 & \\
\hline v 26-33 & エラムとの和平 & \\
\hline
\end{tabular}

\begin{tabular}{|c|c|c|}
\hline No. 30 & 遠征地 & $\begin{array}{c}\text { 反乱 } \\
\text { 描写 }\end{array}$ \\
\hline $1^{\prime}-12^{\prime}$ & 海の国 & 有 \\
\hline $13^{\prime}-15^{\prime}$ & ガンブルの貢納 & \\
\hline $16^{\prime}-17^{\prime}$ & アルザー & 有 \\
\hline $18^{\prime}-19^{\prime}$ & キンメリア人 & \\
\hline r. $1^{\prime}-11^{\prime}$ & ティルス & 有 \\
\hline
\end{tabular}


乱として明記されていない。

i）No. 2 において反乱として明記されない反乱

No. 2が言及するシドン, アルザー, ヒラック, マンナイ, 海の国に対する遠征を主題とした記 事のうち, ヒラックとマンナイに関する遠征記事が反乱について沈黙するのは, 戦果が芳しくなかっ たという不都合な事実の隠蔽と関係したと推測される。これら2つの国に関する遠征記事は，いず れもエサルハドンの勝利を伝えている（No. 2, ii 10-15, ii 20-21）。しかし, エサルハドンの後継者 アッシュルバニパルの碑文は，ヒラックの支配者サンダサルメを「私の父である王たちにひれ伏さ

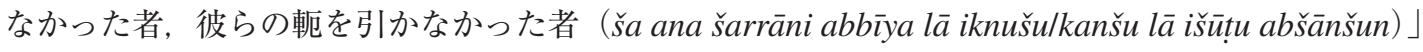
と呼び（Borger 1996, Prisma A 8, ii 76-77; B, ii 74; C, iii 105), マンナイの支配者アフシェリが先 代のアッシリア王たちに貢納義務を果たさなかったと述べていることから（Borger 1996, Prisma A, iii 23-24; B, iii 98-99; C, iv 124-126), エサルハドンはこれらの地に対する支配権を回復できなかっ たと推測できる。

これらの事例とは異なり, シドン, アルザー, 海の国に対する遠征は, エサルハドンにとって満 足いく結果に終わったように見える。王はシドンを征服し，その支配者アブディ・ミルクーティを 処刑してニネヴェで首を晒した(No. 2, i 50-56)。アルザーについても, 支配者アスヒーリはニネヴェ に連行され, 動物とともに城門に繋がれた（No. 2, i 58-63）。そして, 海の国の支配者であるナブー・ ゼール・キッティ・リーシルはエラムに逃亡したものの, 同地で死亡し, 彼の兄弟ナイド・マルドゥ クがエサルハドンに服従して海の国の支配者に擁立された（No. 2, ii 32-33）。

反乱した支配者の処罰あるいは新しい支配者の擁立など, 十分な戦果を上げているにもかかわら ず，No. 2 はこれらの出来事を反乱として描くことはない。この碑文が意図的に反乱に関する情報 を隠蔽したことは，とくに海の国の反乱記事から明らかになる。

一般に王碑文よりも情報の信頼性が高いとされる歴代記によると, 海の国の知事ナブー・ゼール キッティ・リーシルは, エサルハドンの即位の際の混乱に乗じて蜂起し, 都市ウルを包囲した。ウ ル攻略の失敗後, 彼はエラムに逃亡し, その地で殺害された（Grayson 1975, no. 1, iii 39-41)。し かしながら, No. 2が伝える内容は, 上記の史料が伝えるものとは大きくかけ離れている。No. 2 は, ナブー・ゼール・キッティ・リーシルを「メロダクバラダンの息子，エラム王を頼った者（mār Marduk-aplu-iddina ša ana šar Elamti ittakluma)」と呼び（No. 2, ii 24-25), 彼が王の臣下である 事実にも, ウルに侵攻したことにも触れていない。さらにエラムでの殺害に関しても「彼の命を救 えなかった者 ( ̌̌a...la ušězibu napšātsu)」という表現で暗示するにとどまり（No. 2, ii 26）, 彼とと もに逃亡した彼の弟ナイドゥ・マルドゥクの服従と海の国の支配者としての擁立を伝える（No. 2， ii $32-33)$ 。

アッシリア王の臣下という来歴が語られず, エラム王を頼った者として記された事実は, ナブー・ ゼール・キッティ・リーシルを反乱者ではなく外敵として描こうとしたように見える。たしかにサ ルゴン 2 世（在位前 721-705年）とセンナケリブ（在位前 704-681年）の治世にバビロニアの王位 を篡奪した反乱者メロダクバラダンとの血縁関係を明示することは, ナブー・ゼール・キッティ・リー シルを反乱者として描く狙いがあったと考えることもできる。しかし， センナケリブの碑文は，第 一回遠征直後に編集された碑文を除き（RINAP 3/1, no. 1, 5-56），メロダクバラダンを反乱者とし 
て描くことはない。「メロダクバラダン」という名は，時を経るごとに，長きにわたってアッシリ アによるバビロニア支配を妨害した敵としての意味合いが強くなっていったと推測される。ナブー・ ゼール・キッティ・リーシルをその息子と呼んでいるのは, 彼の敵対的な振る舞いを強調するため だったと考えられる。

さらに, ナブー・ゼール・キッティ・リーシルがエラム王に示したような, アッシリアの周辺に ある強国の王に対する信頼は, 反乱の文脈でのみ言及される。しかし, 天然の要害や城塞などを頼 みにアッシリアに抵抗すること自体は敵全般に共通する描写であり, 必ずしも反乱者に特有なもの ではない。つまり，主題となる人物の来歴に関する知識を持ち，意識的にテキストを読まない限り， この文言からはナブー・ゼール・キッティ・リーシルが外敵か反乱者かについて決定的な示唆を得 られない。No. 2が，ナブー・ゼール・キッティ・リーシルがアッシリア王の臣下だった過去を明 瞭に物語る「海の国の知事 (šakin māt tâmtim)」という肩書きに言及しないのは, 彼を王の支配に 屈しない外敵として描こうとした意図を窺わせる。

ii） No. 2 において反乱として明記された反乱

上述の例から明らかなように, No. 2 は平定に成功していても, 基本的に反乱について伏せる傾 向があったことがわかる。唯一の例外となるのが, ビート・ダックリのシャマシュ・イブニの反乱 に関する記事である。

「バビロンの敵（ayyāb Bābili）」とされるビート・ダックリの支配者シャマシュ・イブニは（No. 2， ii 35), 「ならず者, 強奪者, 主たちの主に対する誓約を怖れない者, バビロンとボルシッパの住民 の土地を暴力で奪った者（ishappu habbilu lā pālihnu zikrī bēl bēlī ša eqlēt mārī Bābili u Barsipa ina parikti itbaluma)」と呼ばれ，明確に反乱者として描かれる（No.2, ii 37-39）。

この出来事に関する記事は, バビロンと極めて密接に結びつけられた叙述となっている。「バビ ロンの敵」という表現は無論のこと，シャマシュ・イブニが破った誓約も，「主たちの主」，つまり バビロンの主神マルドゥクに誓ったものとされる。

誓約破棄とともに非難されているのは，都市住民が所有する土地の強奪である。王碑文は貢納の 滞納や誓約破棄などの政治的な違反行為を遠征の動機として挙げることが多く，住民の土地の強奪 といった出来事に言及するのは珍しい。当時のバビロン周辺の状況を伝える書簡（Reynolds 2003， no. 60）から，たしかにシャマシュ・イブニ率いるビート・ダックリはバビロン（およびボルシッパ） の住民を苏かしたと思われる。しかし, 碑文は沈黙を保っているが, シャマシュ・イブニの違法行 為はこれだけにとどまらない可能性が高い。むしろ後述する点にこそ, このビート・ダックリの族 長が処刑された真の理由があったと推測される。

ある王室書簡（Parpola 1993, no. 2, 19-r. 7）は，南バビロニアで反アッシリア的活動を展開して いたツイッラーヤが, シャマシュ・イブニを含む 3 人のバビロニアの有力者にアッシリアに対する 反乱を唆したと報告している。シャマシュ・イブニはこの人物と手を組んだと考えられる（Frame

（８）この神のエピセットについてはTallqvist 1938, 42を参照。

（９）アッシリア王碑文が挙げる遠征理由についてはOded 1992 を参照。

(10) さらに, エサルハドンがある書簡 (Reynolds 2003, no. 1) で悪事を非難する「バビロニア人ではない者」は, シャ マシュ・イブニを指すと考えられる（Frame 1992, 80)。

(11) ッィッラーヤに関する概要はReynolds 2002,1174を参照。 
$1992,80)$ 。

しかしながら, No. 2 は王碑文の主題としてょり相応しい出来事であるはずのシャマシュ・イブ ニによる反乱計画への関与には一切言及しない。この碑文が提示するバビロンに仇為す者という シャマシュ・イブニ像は，エサルハドンが行なった対バビロニア政策と関係していたと推測される。 エサルハドンは, センナケリブが破壊したバビロンの再建を通じてバビロニアに対して宥和政策を とっていた（Frame 1992,67-69）。こうした政策をとる王のもとで編集された碑文において，この 都市の庇護は一族長の反乱鎮圧よりも優先して記すべき出来事だったと考えられる。なによりこう した脅威の排除は, バビロンの安寧を保障する支配者としての姿を強調し, エサルハドンのバビロ ニア支配を正当化することにつながる。そのため, 本来なら反乱記事において格好の題材となった 反アッシリア的活動に関与した事実には触れず，土地の強奪に焦点を当てたのだと考えられる。わ ざわざ奪われた土地の返還に言及しているのも（No. 2, ii 40-42）, 王がいかにバビロンの住民に心 を砕いているかを強調する狙いがあったと推測できる。

iii）No. 2 における反乱の記述の傾向とその背景

No. 2では, 十分な成果を上げたと考えられるシドン，アルザー，海の国に対する遠征の記事も一 様に反乱に関して言及しない。こうした反乱情報を伏せる傾向は, 碑文が提示する王のイメージと の関連で解釈する必要があると考えられる。反乱記事は反乱描写を除くと対外遠征を主題とする記 事と区別が困難である。そのため, 反乱に関する情報を伏せて遠征を記すことで, 王の軍事活動をアッ シリア外部に対する征服活動であるかのように描くことが可能となる。No. 2では, 遠征の成否に関 わらず，反乱に対する懲罰を目的としたほとんどの遠征は未服属の地に対する軍事活動として書き 換えられ，エサルハドンをアッシリアの支配領域を拡大する征服者として際立たせたと考えられる。

唯一ビート・ダックリの支配者シャマシュ・イブニに関する出来事は, こうしたNo. 2 の傾向と は別の, 対バビロニア政策という観点から評価され, 反乱として明記された。そして, エサルハド ンのバビロニア支配を正当化するために，シャマシュ・イブニはバビロンを脅かす反乱者として描 かれたのである。

\section{No.1における反乱の記述}

No. 1では, No. 2が記すシドン, アルザー, ヒラック, マンナイ, 海の国, ビート・ダックリに 関する記事に加え，エサルハドンの即位に関係する騒乱を主題にした「弁明」とアラブ派兵に関す る記事が追加される。No. 2でも主題となった出来事のうち, ヒラック, マンナイ, アルザー, そ してビート・ダックリに関する記事は, No. 2 の記事と内容が共通している。その一方, シドンと 海の国に対する軍事行動は反乱鎮圧として明記され，さらに碑文の中央部にあった海の国の記事は, 遠征記事の先端に置かれた（表 1 )。

i） No.1において反乱として明記されない反乱

No. 1において反乱として明記されなかった記事は, ヒラック, マンナイ, そしてアルザーに対

（12）エサルハドンがバビロニアに対し，自身を正当なバビロニア王として喧伝した戦略についてはPorter 1993, $77-117$ を参照。 
する遠征を扱う記事である。このうち，ヒラックとマンナイに対する遠征は不成功に終わったため， これらの記事はNo.1においても反乱に関して沈黙を保ったと考えられる。

これに対し，アルザーに対する遠征は戦果を上げたにもかかわらず，後述する海の国とシドンの 記事とは異なり，依然として反乱平定という遠征理由が明かされることはない。このことは, No. 1編集時において，アルザーの反乱が反乱として明記されるべき出来事ではないと判断されたこと を示す。これについてはNo. 30の考察（以下V.3.）において説明したい。

ii） No.1において反乱として明記された反乱

No. 1において反乱記事として記された海の国とシドンに対する遠征およびNo. 1から追加された 「弁明」は，いずれもNo. 2が反乱鎮圧という遠征理由を伏せて軍事行動を記したか，あるいは軍事 行動を含めた一切の情報を隠蔽した出来事である。「弁明」は碑文の冒頭に配置され, 海の国とシ ドンに関する記事がこれに続くため,この3つの記事は一つのまとまりを形成していると考えられる。

一方, ビート・ダックリの記事とNo. 2 の編集後に起きたアラブの反乱に関する記事は, いずれ も碑文の中央部に記載される。これら 2 つ記事は, 「弁明」, 海の国, シドンの記事とは離れた位 置にあるため, 相互の関連性はなかったと推測される。

まずは「弁明」をはじめとした一連の記事における反乱描写を概観した後, 記事の背景を考察する。 エサルハドンの「弁明」の大筋は以下の通りである。センナケリブは年長の息子たちを差し置き， 末子のエサルハドンを皇太子に指名した。しかし，

迫害の衝動と䃚妬が私（＝エサルハドン）の兄弟たちに降り注ぎ，彼らは神々（の意志）を無 視した。彼らは自分たちの傲慢な行いを頼り，悪いことを企んだ。彼らは悪しき言葉，誹謗 中傷を神の意志に反して私の上に在らしめ, 偽りと嘘と敵意（ある言葉）を私の背後で絶え 間なく語った。彼らは神の意に反して，私の父の心を私から離れさせようとした（riddu qinû eli ahhīya ittabikma ša ilāni umašširūma ana epšêtišunu šurruhāti ittaklūma ikappudū lemuttu lišān lemuttim karși tašgirti kī lā libbi ilāni eliya ušabšûma surrāti lā šalmāti arkiya iddanabbubū zērāti pašru libbi abiya ša lā ilāni uzennû ittiya)。(No. 1, i 23-29)

センナケリブの決定を不満とするエサルハドンの兄弟たちによって, 宮廷内は不穏な空気に満ち た。神々の庇護のもと，エサルハドンは一時的に身を隠したが，彼の兄弟たちは王座をめぐり争い， 国内は内乱状態に陥った。これをみたエサルハドンは軍を率いてニネヴェに進軍した。アッシリア の住民はエサルハドンに平伏し，エサルハドンは神々の支援をうけて反対勢力を撃ち破り，無事王 位に就いた（No. 1, i 8-ii 11）。

この記事では, 神々と前王の意志に従わない王の兄弟たちによる, 宮廷内での皇太子に対する誹 謗中傷と院謀画策がテーマとなっている。これらはNo. 1 編集の翌年にアッシリア王の臣下に発行 された「エサルハドン王位継承誓約文書」で禁じられた行為であり，おそらくこの誓約文書が意識

（13）アラブに関する出来事の年代についてはEph`al 1982, 125-126を参照。

（14）この箇所の表現と訳についてはフラームの訳（Frahm 2009, 45）に従う。 
されていたと考えられる。

海の国の記事に関しては, No.1において記事の内容が大幅に変化する。この碑文は, ナブー・ゼー ル・キッティ・リーシルが海の国の知事であった事実を明示するとともに（No. 1, ii 40), 彼を「反 乱者 $(b \bar{a} r a \bar{a} n \hat{u})\rfloor$ と呼ぶ (No. 1, ii 54)。そしてナブー・ゼール・キッティ・リーシルは,

誓約を守らない者, アッシリアの恩を覚えていない者は, 私の父による良き行いを忘れた。彼 はアッシリアの混乱時に軍と兵を召集し, ウルの知事ニンガル・イッディナ, 私の僕, 私にひ れ伏す者を包囲し, その出口を閉ざした。アッシュル, シャマシュ, ベール, ナブー, ニネヴェ のイシュタル，アルベラのイシュタルが私エサルハドンを私の父の王座に喜ばしく座らせ，諸 国の支配者を私の前にひれ伏させたが，彼は（私を）怖れなかった。彼は（ウル包囲を）意ら ず，私の僕を解放しなかった。そして，彼は私に使者を送らず，私の王権の安寧を尋ねること もしなかった（lā nāṣir adê lā ḩāsis țābti ša māt Aššur țābtu abiya inš̌̀ma ina dalihti māt Aššur ummānātišs u karāssu idkēma ana Ningal-iddin šakin māt Uri ardiya dāgil pāniya nītu ilmēšuma iṣbatu mūṣ̂šsu ištu Ǎ̌šur Šamaš Bēl u Nabû Ištar ša Ninua Ištar ša Arba-ili yâti Ǎ̌šur-ahu-iddina ina kussî abiya țābiš ušěšibūnimma bēlūt mātāti ušadgilū pāniya šū ul iplah nadê ahi ul irššma ard̄̄ ul umaššir u rakbûšu adi mahriya ul išpuramma šulmu šarrūtiya ul išāl)

と非難されている（No. 1, ii 41-50）。この反乱記事は, No. 2で取り上げられたエラムとの同盟関 係には言及しない。重点が置かれているのは, 臣従義務の不履行である。さらに, ここではこの反 乱がアッシリアの内乱および王の即位した時期に起きたと明記され（No. 1, ii 42, ii 45-47), エサル ハドンが王位につく前から起きたとされる。

海の国の反乱記事におけるもう一つの大きな変化は, ナブー・ゼール・キッティ・リーシル の末路に関する詳しい描写の追加である。No.2では「彼の命を救えなかった者（ napšātsu)」という簡潔な表現で死を暗示されたのみだったが (No. 2, ii 26), No. 1ではこの反乱者 が誓約を破ったために神々が罰を下し, 彼は亡命先のエラムにおいて殺害されたと述べられる（No. 1, ii 55-57)。

海の国の記事と同じく, No. 1において反乱記事として記されたシドンの記事は, アブディ・ミ ルクーティを「私（＝エサルハドン）の支配権を怖れない者, 私の口からの言葉を聞かない者, 波 打つ海を頼ってアッシュル神の軛を放棄した者（lā pālih bēlūtiya lā šêmû zikir šaptiya ša eli tâmtim gallatim ittakluma islû nīr Aššur)」として描く（No. 1, ii 66-67）。この反乱描写では, 貢納義務の 不履行などの特定の反乱行為と結びつく表現はなく, 王に対する畏敬の欠如, 王の命令とアッシュ ル神の軛への不服従という，包括的に反抗を表すものが中心となっている。

このアブディ・ミルクーティに関する描写は, 意図的に選択された可能性が高い。シドンの記事 に続くクンドゥとシッスー征服の記事によると, サンダウアッリとアブディ・ミルクーティは相互 支援のために軍事同盟を結んだ（No. 1, iii 24-27; 2, i 43-46)。敵同士の軍事同盟は, 反乱記事にお

（15） テル・タイナトから出土した粘土板も含めた「エサルハドン王位継承誓約文書」の最新の編纂は渡辺 2017 を参照。エサルハドンの兄弟たちの振る舞いと類似する箇所としては, 例えば渡辺 2017, 200, 11. 62-72; 205, 11. 123-129; 216, 11. 318-327が挙げられる。 
いて格好のテーマとなるにもかかわらず，シドンの反乱記事はこれに触れることはない。そのため， この反乱者が処罰された実際の理由は背後に追いやられたと推測できる。

No. 1において,「弁明」, 海の国, そしてシドンの3つの記事は, 「弁明」を筆頭に碑文の冒頭部 に記された。No.2では遠征記事の中程にあった海の国の記事が, No. 1では遠征記事の先端に移動 していることから（表1），こうした記事の配置が特定の意図に基づいたことは明らかだろう。以下 の表 2 は, 碑文冒頭部からシドンの記事までの内容を要約したものである。

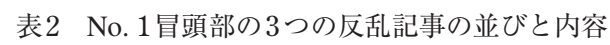

\begin{tabular}{|c|c|c|c|c|}
\hline 出典 & 内容 & 勃発時期 & 反乱者 & 反乱の内容 \\
\hline i $1-8$ & 導入部（1） & & & \\
\hline i 8-ii 11 & 「弁明」 & 王の即位以前 & 王族 & 王宮内での策謀，クーデター \\
\hline ii $12-39$ & 導入部（2） & \multicolumn{3}{|c|}{ 王権の確立（即位） } \\
\hline ii $40-64$ & 海の国 & 王位継承戦争中 & 州知事 & 臣従義務放棄，他の属王への攻撃 \\
\hline ii $65-$-iii 19 & シドン & 即位以後 & 属王 & 王に対する包括的な不服従 \\
\hline
\end{tabular}

No. 1の冒頭部は, 構成的に2つの導入部を含んでいる。碑文は導入部（1）の「エサルハド ン, 偉大な王 (中略) の王宮 (ekal A ̌̌šur-ahu-iddina šarru rabû...)」で始まり,「弁明」において 王位継承の経緯が語られる。その後, 「私, エサルハドン, 世界の王（anāku Aššur-ahu-iddina šar

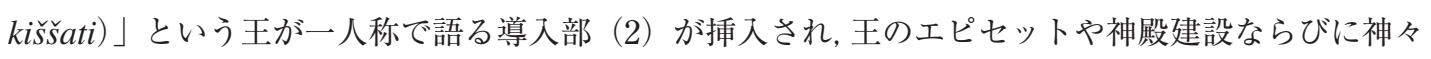
による王への特質の授与が続く（No. 1, ii 12-39）。導入部（2）は, 先行する導入部（1）の補足や 拡充を目的としていなかったように見える。むしろ, 改めて王権の確立をテーマとした導入部を繰 り返すことで, 王位継承の騒乱を主題とする「弁明」と, それ以降に言及される軍事活動とを明確 に切り離すのが狙いだったと推察される。これにより, 語られる出来事は時系列的に即位以前と以 後に区分けされたのである。

しかしながら, 構成的には分けられるが,「弁明」と海の国の記事の伝える反乱は, 時期的に関 連した出来事として記される。海の国の記事によると,ナブー・ゼール・キッティ・リーシルは「アッ シリアの混乱時に（ina dalihti māt A ššrur)」反乱を起こし（No. 1, ii 42），それはエサルハドンの即 位後も続いた（No. 1, ii 45-47）。これら2つの時を表す文言によって, この反乱はアッシリアの混乱, つまり「弁明」が主題とする出来事を時系列的な起点として描かれるのである。海の国の記事に続 くシドンの記事には時系列を示す文言はないため, 王の即位後に起きた反乱を記していると考えら れる。

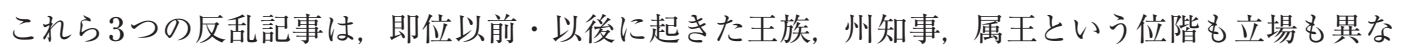
る者たちが主導した 3 種類の反乱を提示する。この3つの反乱記事は反乱を主題とした一つのまと まりをつくり，王族の宮廷内反乱を禁じ，臣下が守るべき数々の臣従義務を挙げ，そして王に対す る服従と忠誠を喚起するのである。シドンの記事が軍事同盟という具体的な違反行為に言及しな

（16）これに類似した構成は, シャムシ・アダド5世 (在位前 823-811年)の年代記 (RIMA 3, A.0.103.1) にもみられる。 この碑文は冒頭で王位継承戦争の終結に言及した後（i 39-53），これ以後に行なわれた王（の代理人）による遠征 を「遠征 (girru)」で数える (i 53, ii 16, iii 34, iii 70)。 
かったのは, 一連の反乱記事の締めくくりとして, 王に対する包括的な服従と忠誠を前面に押し出 すためであったと推測される。

No. 1 におけるこうした反乱に関する叙述の変化は, この碑文が編集された前 673 年の前後に起き

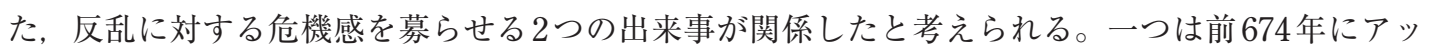
シリアが喫したエジプトでの敗北であり，エサルハドンの権威の失墜とアッシリアの支配に対する 反乱の勃発が危惧された (Eph`al 2014, 58-60)。もう一つは前672年に行われたアッシュルバニパ ルの皇太子任命である。自身の経験から, 長子ではないアッシュルバニパルを後継者に指名するこ とは反発が想定され, エサルハドンはアッシュルバニパルの即位に障害となり得るものを少しでも 排除すべく，臣下に皇太子への忠誠を誓わせ，「エサルハドン王位継承誓約文書」を発行した（渡 辺 2017, 12-13)。

「弁明」は，神々と前王の意志に反した王の兄弟たちの振る舞いを非難する一方で, 前王センナ ケリブによる皇太子指名, 神々の承認, アッシリアの臣民の服従という3つの観点からエサルハド ンの王位の正当性を強調した。それはまた，末弟であるエサルハドンの王位の正当化を通じて，長 子ではないアッシュルバニパルの王位継承を正当化することにもつながった（Tadmor 1983, 45-47）。

また, No. 1の海の国の反乱記事は, 数々の臣従義務の不履行を挙げることで, 臣下の果たすべ き義務を提示したのに加え, 反乱者の死を誓約違反に対する神罰と結びつけて語る。この記述の 変化も，翌年に控えた「エサルハドン王位継承誓約」が念頭にあり，誓約を破った際にはアッシリ アから遠く離れた地に逃れても神々が神罰を下すことを再確認させる狙いがあったと考えられる (Tadmor 1983, 46-47)。

こうした点からも, No. 1の冒頭部に配置された反乱記事は, No. 1編集時の政治状況を反映し, エサルハドンの王位の正当性の喧伝と反乱を企む者に対する警告の役割を果たしていたのだと考え られる。

一方, ビート・ダックリに関する記事とアラブに関する記事は「弁明」, 海の国, そしてシドン の反乱記事とは異なり, 碑文の中央部に置かれた。その位置関係から, ビート・ダックリに関する 記事とアラブに関する記事は，これら3つの記事とは異なる観点から記されたと考えられる。

ビート・ダックリの支配者シャマシュ・イブニの反乱は, No. 1においても記される。記事の内 容に変化がなかったのは, No. 1編集時においても, エサルハドンのバビロニア政策に変更がなかっ たためだと推測される。

アラブに関係する記事は, No. 2で言及されるハザエルの貢納からヤター擁立までの出来事に加 え（No. 2, ii 46-iii 8), ウアブのヤターに対する蜂起を伝える。No. 1 の記事によると, ウアブは「王 権を行使するため, 全てのアラブ人をヤターに対して反乱させた（ana epē̌s šarrūti Arubu kalîšu eli Iata’ ušbalkitma)」(No. 1, iv 23-24)。これに対し，エサルハドンはヤターを救うべく軍を派遣した。

この記事がエサルハドンによる属王の庇護を主題としていることは明白だろう。注目しておきた いのは, ここで提示される臣下の庇護者としての王の姿が, 王位継承戦争を主題とする「弁明」と の類似を通じて一層際立てられた点である。すなわち「弁明」とアラブの反乱記事は，1）エサル ハドンの皇太子任命（No. 1, i 8-i 22）とヤターの擁立（No. 1, iv 19-22）, 2）王の兄弟の謀反（No. 1, i 23-i 44）とウアブの蜂起（No. 1, iv 23-24）, そして3）神々による庇護（No. 1, i 45-ii 11）と エサルハドンによる庇護（No. 1, iv 25-31）という対応関係にある。 
こうした構成上の類似に加え，3）において庇護者として登場する神々と王のエピセットも酷似 したものとなっている。「弁明」において，エサルハドンを支援する神々（アッシュルとマルドゥ

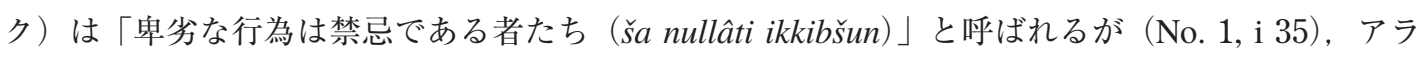
ブの反乱記事ではエサルハドンは「正義を愛する者, 嘘が禁忌である者（ša kittu irammuma șaliptu

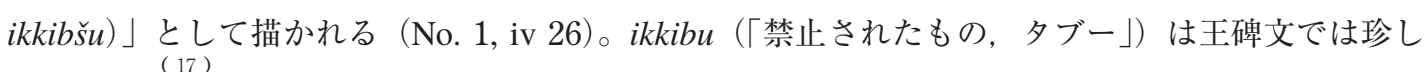
い表現であり，この語の使用からも，この箇所が意図的に重ねあわされたことがわかる。こうした 類似を通じて，エサルハドンは神々が自分を支援してくれたように，苦境にある臣下に救いの手を 差し伸べる慈悲深い宗主として描かれたのである。

iii） No. 1における反乱の記述の傾向とその背景

No. 1 はNo. 2 とは異なり, 不成功に終わった懲罰遠征を除き, 反乱に関する情報をむしろ積極 的に開示した。No. 1における反乱に関する記述の変化は, この碑文の編集時に増大した反乱に対 する危機感が大きく影響したと考えられる。No. 1編集の数年後に起きたエサルハドンによる臣下 の肃清も，王を取り巻く状況がいかに緊張に満ちたものであったかを窅わせる（Knapp 2016, 186187）。このような状況に拈いて, No. 1 は碑文冒頭部において王族, 州知事, 属王による 3 種類の反 乱と反乱者の末路を提示し， エサルハドンの王位の正当性を再確認させるとともに，あらゆる支配 エリート層に対して叛意を抱かぬよう警告したのだと考えられる。

その一方で, ビート・ダックリとアラブの反乱に関する記事は, 上述の政治状況とは別の観点か ら記された。これらの記事は脅かされた臣下に対するエサルハドンの庇護をテーマとしており, そ れを通じてエサルハドンの宗主としての正当性が強調されたのである。

\section{No. 30 における反乱の記述}

前 671 年以降に編集された碑文の断片であるNo. 30 は, 海の国, アルザー, そしてティルスの反 乱を明記する。この碑文において, 海の国の記事はNo. 1のものよりも簡約され, さらに記事の並 びもNo. 1 とは異なる（表1）。しかし，碑文の全容が不明なため, 詳しい考察は困難である。それ ゆえ，ここではアルザーの反乱記事のみ考察する。

No. 30 において, アルザーの支配者アスヒーリは王の䡉を放棄したとされ（No. 30, i 17'）, 初め て反乱者として登場する。すでに述べたように, 反乱情報を開示する傾向があったNo. 1 においても， 成功に終わったアルザーに対する遠征は反乱鎮圧として明記されない。このことは, アルザー遠征 がNo. 1において反乱記事として記された海の国やシドンの記事とは別の観点から評価されたこと を示す。

アルザーを含む地域はティグラト・ピレセル 3 世以降, エジプトとの国境線として維持されてい た（Na’aman 1995, 112）。エサルハドンの碑文に拈いても，アルザーは「エジプトの小川（nahal

（17）用例についてはAHw 369: CAD I/J, 56-57を参照。

（18）反乱者に対する処罰はそれぞれ異なり，「弁明」で王の兄弟に与した者たちは子孫の断絶（No. 1, ii 8-11），工 ラムに亡命した海の国の支配者ナブー・ゼール・キッティ・リーシルは神々の下した罰によって同地で死亡（No. 1, ii 55-57)，シドンの支配者アブディ・ミルクーティは斬首されている（No. 1, ii 74, iii 32-34）。

（19）タドモールは，海の国の反乱記事を「覚えておくべき教訓」と呼ぶが（Tadmor 2004，271），これは「弁明」 からシドンの反乱記事までを範囲とするべきだろう。 
Musri)」にあると記され（No. 1, iii 39; 2, i 57)，ア） アッシリアの「世界」の果てに位置した。

王碑文において, 海や川などの境界や「世界」の果てへの到達やそれを越えた進軍は, 王の英雄 的行為を際立たせる出来事としてしばしば喧伝された（Tadmor 1999-2000, 56; 山田 2003b)。しか し記事の主題として，「世界」の果てと反乱とは相容れないものであった。なぜなら，反乱とは支 配下にあることを前提にした出来事であり，反乱鎮圧を主題とした場合，王の軍事活動の舞台は， 必然的にアッシリアの支配領域内に限定されるからである。No. 1編集の際, アルザーの記事にお いてはこの点が考慮されたと推測される。つまり，この地が持つ「世界」の果てという地理的状況 が重視され, 王の境界到達を描くために反乱に関する情報は伏せられたのである。しかし, 前 671 年, エサルハドンはエジプトを征服した。No. 30の編集時にはアッシリアの「世界」はアルザーを越え て広がったため, この地は「世界」の果てとしての重要性を失った。それにより, No. 30 はもはや アルザーの反乱について伏せる必要がなくなり, 同地に対する軍事行動を反乱者に対する懲罰とし て明記したのである。

\section{VI. おわりに}

本稿ではエサルハドンの王碑文を例として，アッシリア王碑文の反乱に関する記述を考察した。 王碑文における反乱の記述は, 反乱として明記するか否かの選択に加え, 反乱として明記する場合 においても入念に情報操作が施されたものであった。

本研究で明らかにしたように, 反乱は懲罰遠征の成否だけではなく, 個々の碑文の叙述傾向, 碑 文編集時の政治状況，あるいは反乱に特有の事情などが絡み合わされて考慮された上で記された。 そして, 新しい碑文編集の際には様々な観点から再評価され, 肯定的・否定的評価が変化する出来 事であった。こうした反乱記述の特殊性に焦点を当てた考察は, 他の王の碑文においても続けてい く必要がある。それによって得られる知見は, 王碑文研究の更なる進展を可能にするであろう。

\section{参照文献}

Borger, R. 1996: Beiträge zum Inschriftenwerk Assurbanipals: Die Prismenklassen A, B, C =K, D, E, F, G, H, J und T sowie andere Inschriften, Wiesbaden.

Eph ${ }^{\mathrm{c}} \mathrm{al}$, I. 1982: The Ancient Arabs: Nomads on the Borders of the Fertile Crescent $9^{\text {th }}-5^{\text {th }}$ Centuries B. C., Jerusalem.

Eph'al, I. 2014: "Stages and Aims in the Royal Historiography of Esarhaddon," Orient 49, 51-68.

Frahm, E. 2009: "Warum die Brüder Böses planten: Überlegungen zu einer alten Crux in Asarhaddons 'Ninive A'-Inschrift," in W. Arnold et al. (eds.), Philologisches und Historisches zwischen Anatolien und Sokotra: Analecta Semitica in Memoriam Alexander Sima, Wiesbaden, 27-50.

Frame, G. 1992: Babylonia 689-627 B.C.: A Political History, Istanbul.

Grayson, A. K. 1965: "Problematical Battles in Mesopotamian History," in H. Güterbock and Th. Jacobsen (eds.), Studies in Honor of Benno Landsberger on His Seventy-Fifth Birthday, April 21, 1965, Chicago, 337-342.

Grayson, A. K. 1975: Assyrian and Babylonian Chronicles, New York.

Grayson, A. K. 1980: "History and Historians of the Ancient Near East: Assyria and Babylonia,” Or. 49, $140-194$.

（20）「エジプトの小川」は現在のワディ・エル・アリシュと考えられる。位置に関する議論は Na’aman 1979, 74-80 を参照。 
Grayson, A. K. 1991: Assyrian Rulers of the Early First Millennium BC (1114-859 BC), I, RIMA 2, Toronto.

Grayson, A. K. 1996: Assyrian Rulers of the Early First Millennium BC (858-745 BC), II, RIMA 3, Toronto.

Grayson, A. K. and J. Novotny 2014: The Royal Inscriptions of Sennacherib, King of Assyria (704-681 BC), vol. 1, RINAP 3/1, Winona Lake.

Knapp, A. 2015: Royal Apologetic in the Ancient Near East, Atlanta.

Knapp, A. 2016: “The Sitz im Leben of Esarhaddon's Apology,” JCS 68, 181-195.

Laato, A. 1995: “Assyrian Propaganda and the Falsification of History in the Royal Inscriptions of Sennacherib," VT 45, $198-226$.

Leichty, E. 2011: The Royal Inscriptions of Esarhaddon, King of Assyria (680-669 BC), RINAP 4, Winona Lake.

Na'aman, N. 1979: “The Brook of Egypt and Assyrian Policy on the Egyptian Border," Tel Aviv 6, 68-90.

Na'aman, N. 1995: "Province System and Settlement Pattern in Southern Syria and Palestine in the Neo-Assyrian Period," in M. Liverani (ed.) Neo-Assyrian Geography, Rome, 103-115.

Oded, B. 1992: War Peace and Empire: Justifications for War in Assyrian Royal Inscriptions, Wiesbaden.

Parpola, S. 1993: Letters from Assyrian and Babylonian Scholars, SAA 10, Helsinki.

Porter, B. N. 1993: Images, Power, and Politics: Figurative Aspects of Esarhaddon's Babylonian Policy, Philadelphia.

Reynolds, F. 2002: "Șillāia," in H. D. Baker (ed.), The Prosopography of the Neo-Assyrian Empire, vol. 3/1, Helsinki, 1174.

Reynolds, F. 2003: The Babylonian Correspondence of Esarhaddon and Letters to Assurbanipal and Sin-šarru-iškun from Northern and Central Babylonia, SAA 18, Helsinki.

Tadmor, H. 1983: “Autobiographical Apology in the Royal Assyrian Literature,” in H. Tadmor and M. Weinfeld (eds.), History, Historiography and Interpretation, Jerusalem, 36-57.

Tadmor, H. 2004: “An Assyrian Victory Chant and Related Matters," in G. Frame (ed.) From the Upper Sea to the Lower Sea: Studies on the History of Assyria and Babylonia in Honour of A. K. Grayson, Leiden, 269-276.

Tadmor, H. 1999-2000: "World Dominion: The Expanding Horizon of the Assyrian Empires," in L. Milano et al. (eds.), Landscapes: Territories, Frontiers and Horizons in the Ancient Near East; Papers Presented to the XLIV Rencontre Assyriologique Internationale Venezia, 7-11 July 1997, Padova, 55-62.

Tallqvist, K. L. 1938: Akkadische Götterepitheta, Hildesheim.

Yamada, S. 2000: The Construction of the Assyrian Empire, Leiden.

青島忠一朗 2016 :「アッシリア王碑文における反乱の記述と情報操作：アッシュルナツィルパル 2 世の王碑文を例と して」『オリエント』59/1, 14-26.

山田重郎 2003a：「前9世紀アッシリアにおける年代記 : 形式の変容とその背景」『オリエント』46/2, 71-91.

山田重郎 2003b：「アッシリア王室碑文における数字操作とプロパガンダ」『史境』46,28-41.

渡辺和子 2017 :『エサルハドン王位継承誓約文書』楔形文字文書研究 1, リトン。 